\title{
Religion and cultural change
}

DOI: https://doi.org/10.30664/ar.114539

Attribution 4.0 International (CC BY 4.0)

T he current issue of Approaching Religion is based on a summer school and conference arranged in Åbo/Turku, Finland, in June 2021, with the theme 'Religion and Cultural Change'. The event was organized jointly by the Polin Institute for Theological Research (Åbo Akademi University), the Centre for the Study of Christian Cultures (University of Turku), and the Donner Institute for Research in Religion and Culture. The aim was to bring together doctoral candidates and researchers from various academic fields who engage with the study of religion, such as theology, religious studies, history, philosophy, the arts, social and political sciences and so forth. This included presentations that engaged with the theme Religion and Cultural Change from both historical and contemporary perspectives, as well as looking to the future where possible. As conference organizers, we wanted to highlight cultural change both as dramatic breaking points in history and as slowly evolving transformations. Hence, the conference theme allowed us to address past, present and emerging trends and trajectories within culture, society and the scholarly community.

THIS BROAD AND INTERDISCIPLINARY approach can also be seen in the current special issue, presenting articles that have been developed based on presentations given at this summer school and conference. We are especially happy to have the opportunity to publish so many articles written by emerging scholars in this issue. Several doctoral students responded to the challenge to develop their presentations at the summer school into strong and innovative research articles, aided by constructive and knowledgeable comments by anonymous peerreviewers, and feedback from peers and supervisors. As a result, the articles present truly novel perspectives and research findings, and innovative approaches to the shared theme.

The issue opens with a review article by Anders Runesson, one of the keynote presentations of the conference. $\mathrm{He}$ addresses one of the great religious and cultural changes in history: the emergence of Christianity and Judaism as distinct religious traditions. Runesson looks at institutional realities in the ancient Mediterranean and challenges older views on how, why and when the 'parting of the ways' happened, if it ever did.

The section of research articles opens with Mikko Pisiläs presentation, in which he analyses the Gospel of Matthew in light of current conversations and conceptualizations of spiritual violence within the Evangelical-Lutheran Church of Finland. Evolution, punishment and violence emerge as relevant, interrelated themes in this analysis. This is followed by Visa Helenius's philosophical analysis of religiously framed, restrictive frameworks for freethinking 
in relation to rationalist approaches and especially Kant's philosophy.

The following two articles deal with religion, music and the arts. Laura Hellsten writes about dancing as a spiritually formative practice within Western Christianity. With a starting point in post-colonial theory and Hannah Arendt's writing, she portrays dance as an agent of change and resistance against totalitarianism. Per Göransson, on his part, contributes with a perspective from human geography. Based on quantitative data sets, he analyses the geography of choirs in Sweden, especially focusing on choirs attached to the Church of Sweden and how the different regional divergences in the map of choirs can be understood.

The subsequent set of four articles focuses on themes such as magic, mysticism and spiritual experiences. Karolina Kouvola discusses stigmatization of magical healing in public discourse in Swedish-speaking Ostrobothnia in Finland at the turn of the twentieth century. By close examination of newspaper articles, the author shows how it was especially through what she calls religious and enlightenment discourses that the stigmatization took place, and through which rural population was portrayed as superstitious and naïve. In their contribution, Jaana Kouri and Elina Hytönen-Ng scrutinize the historical changes and their effects on the role of the researcher within the research on shamanism. They argue that the spread of (neo-)shamanistic practices to Western contexts and the consequent increase in the variety of composition of shamanic communities generated the possibility and need to study shamanism auto-ethnographically, which, they argue, enables a more in-depth study of shamanistic experiences.

Widening the spectre of religious experiences explored, Katarina Johansson's article focuses on the concepts used in research to refer to different kinds of religious and spiritual experiences. Through examining the ways in which such concepts have been employed in past research, she ends up arguing for the use of the term 'mystical experiences' as an inclusive and useful umbrella term for studying these phenomena. In the last article of this set, Polina Vrublevskaya seeks to further refine and enhance the applicability of the concept of spiritual quest employed in research on modern Western spirituality. She shows how, despite the variation between cases, among Finnish Lutheran, Polish Roman Catholic and Russian Orthodox young adults, spiritual quest is simultaneously characterized by individualization on the one hand, and common seekership habitus on the other.

Olga Sitarz, Anna Jaworska-Wieloch and Jakub Hanc contribute to the issue with a perspective on religion and law, focusing on societal and juridical responses to questions concerning the right to religious freedom in prisons. Their case study focuses on the current situation in Poland, in relation to international legislation. Maria Lindebæk Lyngsøe and Teemu Pauha both focus on the cultural change experienced by contemporary Muslims in Europe. Lyngsøe's field study on Muslim women in Denmark during the Covid-19 lockdown sheds light on the new opportunities for education opened up by new technology as well as loss of spaces of bodily and sensory togetherness, experienced before the lockdown. Pauha applies dialogical self theory in conceptualizing the different religious identities and authorities of young European Muslims.

We hope that readers enjoy the timely and engaging topics discussed by the articles in this issue of Approaching Religion. We are also pleased to announce that 
a follow-up to this successful summer school is planned for the summer of 2023, under the topic 'Religion: Memory and Innovation'.

\section{ANNI MARIA LAATO, Guest Editor MINNA OPAS, Guest Editor RUTH ILLMAN, Editor}

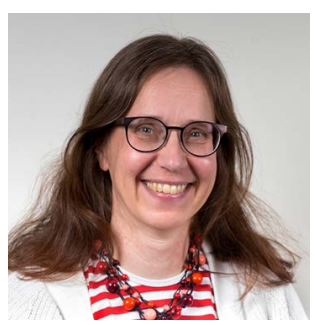

Dr Anni Maria Laato is lecturer in Systematic Theology at Åbo Akademi University. She holds the title of docent in patristics at the University of Helsinki, and in dogmatics at Åbo Akademi University. She is the chair of the Finnish Patristics Society. Her main research interests include ecclesiology, encounters between religions, both in antiquity and today, reception history of the Bible and women in early Christianity. Website: <https:// research.abo.fi/en/persons/anni-maria-laato/ publications/>

\section{Dr Minna Opas currently} works as Professor of the Study of Religion at the University of Turku, Finland, and holds the title of docent in anthropology of religion from the same university. She is the director of the Centre for the Study of Christian

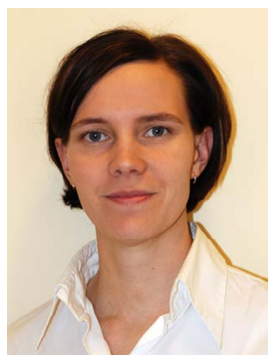
Cultures, and co-editor in chief of the journal Temenos: Nordic Journal of Comparative Religion. Her research focuses on the ethnographic study of indigenous cultures and religions, the anthropology of Christianity, and religion and materiality. Website: <https://www.utu.fi/en/people/ minna-opas>

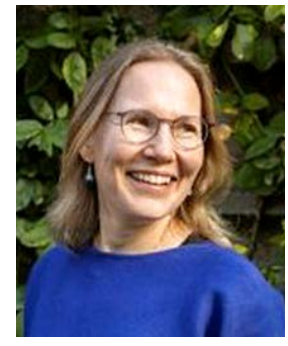

Dr Ruth IIIman is the director of the Donner Institute for Research in Religion and Culture in Turku, Finland. She holds the title of docent in the study or religions at Åbo Akademi University $(\AA A U)$ and in the history of religions at Uppsala University, and has doctoral degrees in the study of religions (2004) and Jewish studies (2018). Her main research interests include cultural encounters and diversity, contemporary Judaism, religion and the arts (especially music) and ethnographic research, primarily by developing the analytical approach of vernacular religion. Website: <https://research.abo.fi/en/persons/ ruth-illman> 